\title{
TAKE IT WITH A GRAIN OF SALT: THE KERNEL OF TRUTH IN TOPICAL JOKES
}

\section{Liisi Laineste}

\section{INTRODUCTION}

Jokes are a vitally important part of everyday discourse. Joking occurs mostly in social situations, but there is an emergent source of jokes circulating on the Internet. The vast number and popularity of jokes proves that jokes possess roles other than those connected with immediate communicational gains. My interest is not to discuss the psychological or social, but rather the cognitive function of humour. This article suggests that jokes possess a cognitive function for both the joke-tellers and readers: jokes are a way of dealing with events in social reality. They help to organize the massive amount of information and experience of contemporary times. Jokes reveal the complexities and paradoxes inherent in living in a rapidly developing society that forces us to work through vast amounts of information from innumerable (mostly one-way-communication) sources: television, newspapers, and the Internet.

The emphasis of this study is on the way people relate to the media in contemporary society, and how this relationship is reflected in news parodies and other topical jokes.

What motivated me to turn my attention to topical jokes was the discussion of the social function of jokes, which has, in my opinion, reached high levels of interesting but fruitless speculation. In my prior research (Joon 2000, Joon 2002) I have examined the nature and possible functionality of neighbourly humour between the Estonians and the Finns, and the use of jokes as part of a PR-campaign. The results showed that in addition to its ambiguous social function, humour functions as a cognitive tool for the joker himself to categorize (i.e. better manage) the paradoxes and complexities of his environment.

I have been fascinated by the nature of topical jokes and the way news parodies have always found a grateful audience. News parody

http://www.folklore.ee/folklore/vol21/jokes.pdf 
is a relatively new genre that first appeared on Estonian radio in around 1995, and is now popular in (the more convenient and accessible) chatroom-type joke portals.

This research is unique from several aspects. First, in a small country like Estonia it is easy to gain valuable and comprehensive information on topical jokes. Secondly, to do research on the basis of the most popular Internet joke book (www.delfi.ee/jokes) is to capture a constantly moving stream. This is not the standing water of printed books nor the rapid stream of joking in oral social situations that is nearly impossible to capture: the jokes appear in real time and interact with each other, forming cycles and causing various reactions from readers. Thirdly, Estonia is a highly computerized country. Many people use the net in their daily work and entertainment and are thus also more or less involved in the creation of Internet joke-lore. And last but not least - the nature of jokes is changing completely. The change is due to a high level of computerization. The nature of jokes has radically changed in computer-mediated communication: situational social performance, context, or reception no longer plays such a central role. This might indicate that the function of jokes has also shifted.

\section{TOPICAL JOKES}

Defining the object of the study - topical jokes - is best done through their content, form and function.

Topical jokes often come in the form of news parody, but slogans, top ten lists or topical pictures/ cartoons can also be included in this category. One can assume that some existing jokes on the same theme will be rediscovered because of their newly acquired salience, i.e. some jokes can be turned into topical jokes because of their salient content.

The content of a topical joke is often an ironic comment on a currently "hot" topic. This implies that topical jokes are strictly tied to their wider context, both social and cultural, they should arise shortly after a triggering event and remain popular for a limited period of time until the theme loses its salience for the public. 
I seek to reveal the function of topical jokes through an examination of their form and content (and the contradictions between them) with the methods of critical discourse analysis.

\section{METHODOLOGY}

Critical discourse analysis consists of three levels of investigation, as defined by Fairclough (1993): description, interpretation and explanation. Description is the analysis of content and form (or texture) on the textual level. Fairclough stresses the importance of comprehensive textual analysis. Interpretation draws conclusions about the level of discursive practice: how the participants interpret the text, how it makes use of interdiscursivity or mixed discourses and genres (Fairclough (1995) offers examples where genres of information, persuasion and entertainment are combined). Explanation goes deeper into social practice. Levels of social organization such as situation, institution, power and ideologies can also be found in topical jokes, especially when their form is institutionally determined, as in the case of news parodies.

\section{General analysis of joke patterns}

General trends in sending jokes to the Internet were calculated on the basis of all entries in the history of the Internet joke book on the largest Internet portal in the Baltic region, http://www.delfi.ee/jokes. Altogether 10,112 items (of which ca 2000 were topical jokes/ news parodies) were analysed statistically to characterize general joking behaviour on the Internet. The following trends were established:

The general trend (see Graph 1: Topical and other jokes on www.delfi.ee) shows a predictable peak shortly after the joke book was opened to the public (i.e. in April/May 2000), then a sharp fall and a consequent steady rise in the number of jokes contributed daily. In analysing topical joke patterns statistically, we find the steady rise to be significant $(\mathrm{t}=7.5, \mathrm{p}=0.000)$ : the number of topical jokes rises an average of 1.175 per day (year 2000) to 1.83 (year 2001) to 2.32 (year 2002).

There were visible trends in respect to weekdays and times of the day, both in the case of topical and other jokes (see Graph 2 and 3: 


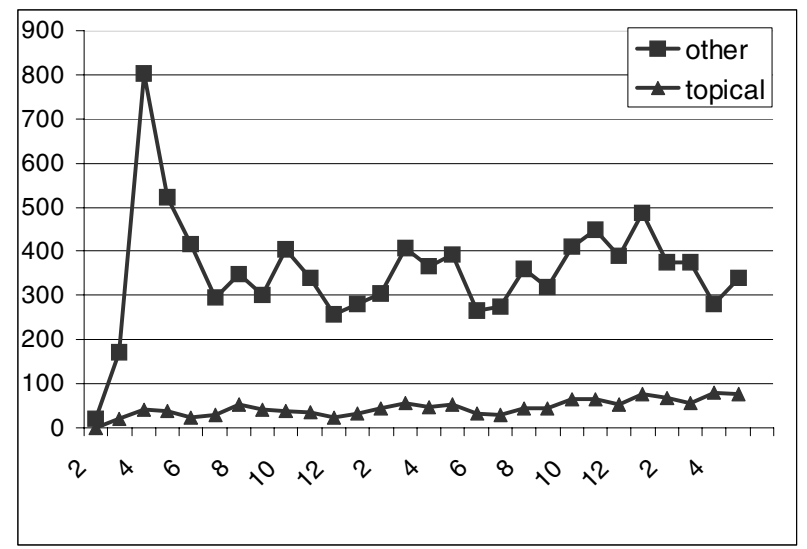

Graph 1. Jokes on http://www.delfi.ee. Number of jokes submitted (x-axis) in the period under observation (numbers indicate months).

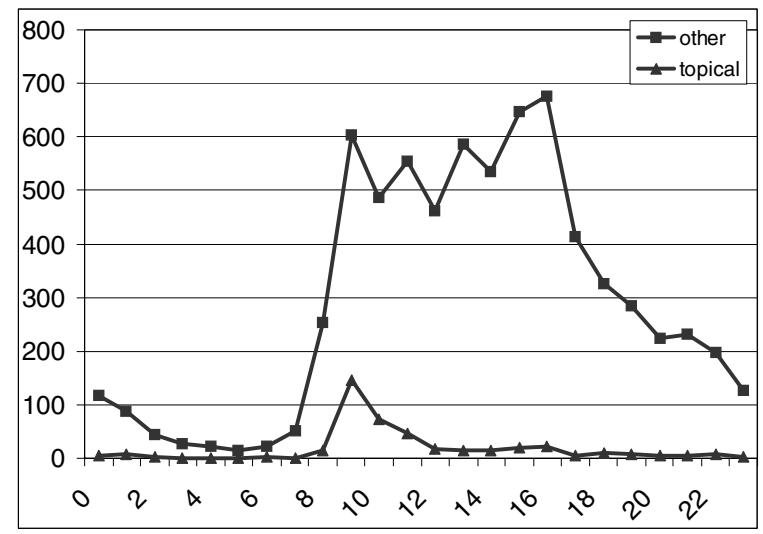

Graph 2. Times of joking. Number of submitted jokes (x-axis) by time of day.

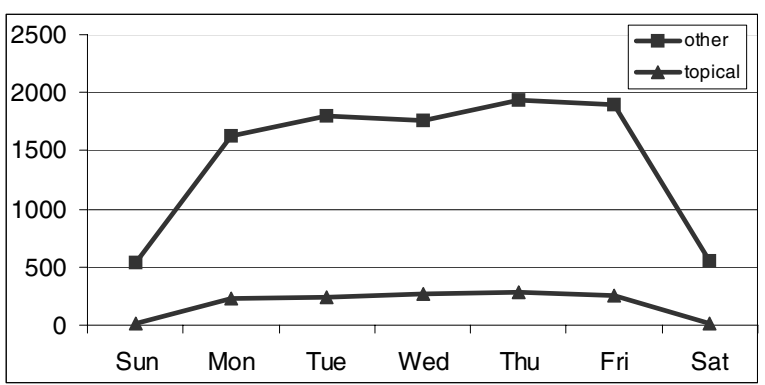

Graph 3. Days of joking. Number of jokes (x-axis) by days of the week. 
Times of joking, Days of joking). The graphs clearly indicate the same pattern that has been established in Internet use in general (see Aikat 1998). The difference between topical and other jokes is most visible in the time of day when jokes are contributed: topical jokes are sent mainly after reading the news, i.e. most likely in the mornings, while other jokes follow the more general trend of entertaining oneself directly after coming to and before leaving the workplace.

In analysing the variance among contributors, we see that there are a limited number of frequent contributors, but in addition there are numerous others who participate in public joking (see Graph 4: Jokes sent by different contributors).

The latency of news becoming news parodies or other topical jokes is short, appearing either on the same day or with a brief delay. Whether it will result in a joke (several jokes, or even a joke cycle) or not depends on the event. The most common subjects for topical jokes are on the one hand minor local news items (e.g. a honeyeating competition in Alatskivi), or issues that cannot be disregarded (the terrorist attack in New York). The trigger in the first case can be a seemingly insignificant detail in the news article: an opportunity for word play, absurdity, etc.

Throughout the existence of the joke book http://www.delfi.ee/jokes, three categories of topical jokes can be differentiated, the first two

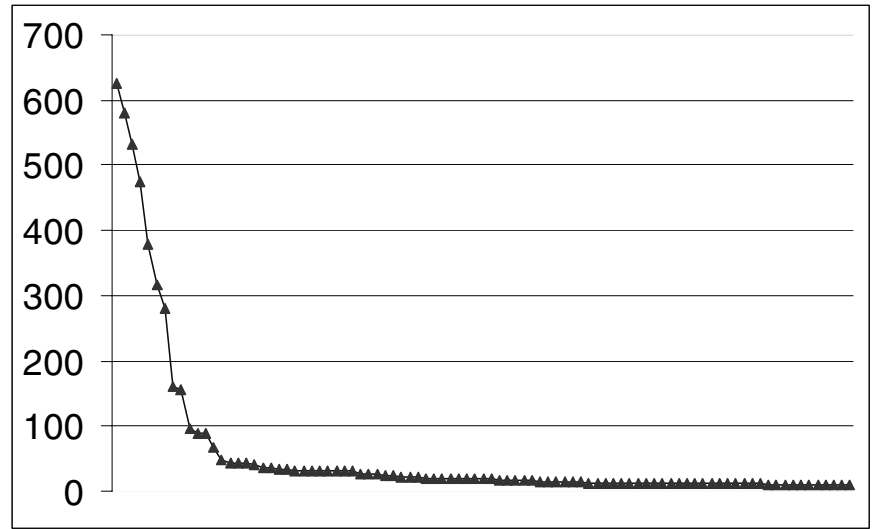

Graph 4. Jokes sent by different contributors. Number or jokes submitted (xaxis) by number of contributors. 
of which are "original" (i.e. created specially for the issue) and the third contains jokes already known to the public:

1. Jokes commenting upon one single event, either local or international. Jokes pertaining to a single news issue are most common. Throughout the material some daily and mostly local events resound in topical jokes, for example:

Civil servants will be charged a third of the full price to see Clinton's presentation. Civil servants will see a Clinton who is wearing not a suit, but instead soiled and greasy overalls and has a bristly and scarred face swollen with hunger. Businessmen who pay the full price will see the usual Clinton. (www.delfi.ee/ jokes; sent by Erkki Kõlu on May 21, 2002).

This kind of news parody refers to existing newspaper articles, usually from the same day (in this case Postimees, May 21, 2002: "Civil servants will see Clinton's presentation at a third of the regular price").

2. Jokes that are a blend of at least two different events - e.g. the common denominator of WTC and methanol catastrophes can easily be found in death, dying, or a world that is coming to its end. Blending local issues with events of international scale is common practice. An Estonian joke from 1963 refers to the Cuban Missile Crisis:

Armenian radio was asked why the Cuban Missile Crisis took place. The answer was: to distract attention from the infamous unfinished construction of the viaduct over Endla Street. (personal communication 2002, Arvo Krikmann).

The generic space is in both cases the feature of a catastrophe or a disaster. News of local value and mild consequences inherit the attributes of a disaster from one of the source domains - that of international catastrophe.

3. Jokes that pertain to a topical subject - e.g. the WTC catastrophe and aeroplane jokes. Other jokes - as compared to topical ones originate from varied themes and are mostly unrelated to daily news. In the case of September 11 jokes, we find many aeroplane-jokes 
because of the weight of the issue and the existing joke-lore on the subject. Thus jokes on relevant themes arise when there is some existing joke-lore on the theme. For example, aeroplane-jokes are quite common, but alcohol jokes usually come in an unsuitable and excessively loaded context (i.e. referring to a particular group of people, e.g. Irishmen), and are not relevant to the discussion of the Estonian methanol catastrophe in September 2001.

\section{EVENTS AND THE BACKGROUND IN SEPTEMBER/ OCTOBER 2001}

September 2001 was a month packed with disasters on both local and international levels. The most important of these found lively reflection in Estonian Internet joke books. On the international level, the September 11 terrorist attack overshadowed all other possible media events. The local Estonian reaction to that catastrophe was preceded and influenced by a national tragedy of nearly 70 deaths caused by the drinking of methanol-tainted bootleg liquor in southwestern Estonia that began on the 10th of September. The emphasis on the local methanol catastrophe is further justified and explained by calculations of the percentage of deaths in USA and Estonia - 50 out of a million is equal to 10,000 out of 250 million which would appear to demonstrate that the Estonians suffered a comparatively greater loss than the Americans (see e.g. article in Eesti Ekspress, Dec. 20, 2001). Issues tied to these topics (e.g. bioterrorism and anthrax) or coinciding in the temporal plane (presidential elections in Estonia) were later also blended into jokes on these topics.

It should also be kept in mind that in the Estonian context, September was already stigmatized as tragic and ominous. An article by Rein Veidemann in Postimees on 14 Sept. 2001 stated that September was a month of mourning, referring to the methanol deaths, and earlier tragedies, such as the sinking of the ferry 'Estonia' (Sept. 28, 1994), the military training accident in Kurkse, northern Estonia (Sept. 11, 1997), etc. 


\section{GENERAL JOKE PATTERNS IN SEPTEMBER/ OCTOBER}

2001

September began with a relatively mild interest in sharing jokes. Until the 11th of September, an average of one topical joke per day was sent to the joke book. The average number of topical jokes then rose to 2.9 after Sept 10 (a statistically significant change, $t=$ 11.2; $\mathrm{p}=0.000$ ), and maintained that rate until the end of October (thereafter falling to an average of 2.4 in November and December). What is even more illustrative is the difference in contribution during weekends: the end of September shows a considerable interest in sharing jokes, both topical and other, during the usually empty days. Here we find the greatest relative differences in deviation from the usual weekday regime: the weekends show an increased number of all kinds of jokes, including topical jokes and news parodies (see also Graphs 5 and 6).

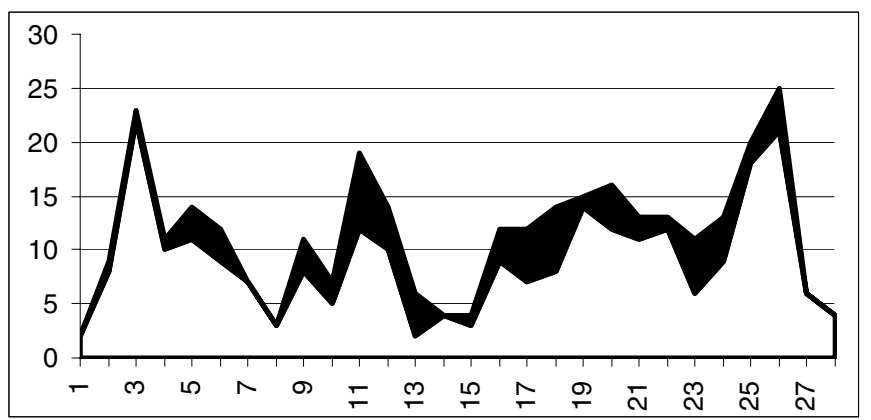

Graph 5. Jokes submitted in September. Number of jokes (x-axis) by days of the month.

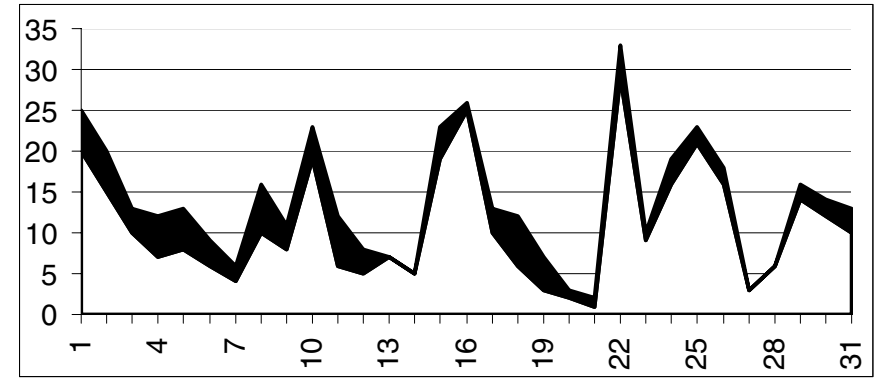

Graph 6. Jokes submitted in October. Number of jokes (x-axis) by days of the month. 


\section{SAMPLES 1 AND 2}

Sample 1 and Sample 2 were the first that commented on the two almost simultaneous catastrophes - one international (the USA terrorist attack) and one local (methanol deaths) - in www.delfi.ee/ jokes. They belong to the first category of "original" topical jokes commenting upon one single event.

\section{Sample 1}

Mon., Sept. 10, 2001; 10:32

Sent by: Valdo Jahilo

The consumption of wood alcohol has claimed the lives of 13 people, 22 are hospitalized. "I do not understand why this happened," the distributor of the wood alcohol said. "I thought nothing bad would happen, because the buyers were all wood-heads."

\section{Sample 2}

Wed., Sept. 12, 2001; 14:00

Sent by: TerroRist Text Unladen

Advertisement: DEMOLITION SERVICE in Manhattan. Information and orders from United Airlines booking offices.

\section{Vocabulary, grammar and structure}

Jokes usually present one keyword that explores an unexpected aspect of an otherwise "normal" text. In Sample 1, the keyword is the idiom "blockhead" (or "woodhead" if translated directly, alluding to "wood-alcohol" as a synonym for methanol'). First we are presented with an honest news-like account of the consequences of the massive consumption of wood-alcohol, and the sincere concern of the public and those responsible. Then we come to the reason for the concern: "I do not understand why this happened [---] I thought nothing bad would happen, because the buyers were all woodheads". What the joke's author implies is that wood-alcohol can be sold to "wood-heads", because they are assumed not to be poisoned by it, and (implicitly) that they are the only ones who are irresponsible and stupid enough to buy it. Sample 2 builds its joke on context-loaded keywords: "Manhattan" (the location of the World Trade Center), and "United Airlines" (whose planes were hijacked to commit the act of terrorism). 
Nominalization ("consumption of wood alcohol") is used in Sample 1 to objectify the suffering group of people. It shifts the responsibility - neither a deficient alcohol policy or the carelessness of methanol producers are to be blamed, but "methanol consumption by the blockheads" led to their misfortune. The literalization of a figurative idiom (e.g. 'woodhead') is a frequent practice in joke-lore. Sample 2 uses straightforward and laconic wording, as appropriate to newspaper ads, where every letter counts. This creates an anonymous atmosphere further reinforced by the passive voice. Both samples use the definite indicative mode, which functions to emphasise the author's wish to be plausible (which is challenged by the overlying joke mode). Subjective and indefinite modality is used only in direct speech (citation) by the methanol distributor to hint at his false assumptions about the effects of consumption of methanol as mentioned in Sample 1.

In both examples the text is incongruous, as dictated by the genre rules of jokes (Raskin 1984). Incongruity is found in the false assumption of the methanol distributor, and in the suggestion that one could obtain information about demolition work from a United Airlines office (which is by common knowledge a national aeroplane company). In Sample 2, we discover the pre-constructed premises of the "ad" by examining the way it is constructed: the first sentence ("DEMOLITION SERVICE in Manhattan") already implies that there exists a target group for such business. The incongruity lies in the absurdity of considering it a normal business among other companies.

\section{Interpretation}

The point where discourses of official news and parody meet determines the interpretation of the joke text. Samples 1 and 2 are interdiscursively quite simple, the generic structure following the rules of two genres: both newspaper articles and jokes, and hinting to the joking mode only with a keyword in the end (Sample 1) or in the text (Sample 2). The meeting point provides a paradox or conflict that leaves one to wonder about the truthfulness of the particular news (and maybe all of the news that we are confronted with daily). 
Important in understanding topical jokes is being aware of antecedent and consequent news texts. Especially in the case of Internet joke books, readers reinterpret the texts continuously on the basis of newly acquired knowledge. The tragedies have happened, they have a strong emotional load and impact, and this cannot be doubted. But from the moment the event takes place, interpretations (including jokes) arise. News interpretations usually follow the principles of some institutionalised discourse (media itself is called the fourth power in society). People take sides, and finally - or immediately, as in the case of immediate topical jokes - sides over the sidetakers are taken - in jokes.

In the case of Sample 1, the first articles in the newspapers were published on September 10, 2001 (on the same day the first joke appeared on www.delfi.ee), the titles being: "Methanol intoxication claims lives of eight people in Pärnu" (Postimees, Sept. 10, 2001), and later "Moonshine drunk at wake of methanol victim" (Postimees, Sept. 18, 2001), "Death through moonshine: guilty or innocent?" (Postimees, Sept. 21, 2001). The majority of the jokes are closely linked to some specific news article on the subject. But the first joke is already reluctant to draw a straight line between guilt and innocence - it adopts an attitude that is at once superior and critical. Sample 2 is preceded by an article entitled "Act of terror in USA forces the implementation of reinforced security measures all over the world" (Postimees, Sept. 11, 2001) and several on-line articles. We notice that the discussion in the official media and in jokes differs far more than in the case of Sample 1: "titles" do not overlap, and, as we see in the analysis of Samples 3 and 4 below, there is a tendency to discuss the issue through local news.

The power that the media holds is intricately woven in Sample 1. The person who sold wood alcohol comments on the issue, while the standpoint of the victims is not mentioned. This, firstly, reinforces the general attitude expressed through newspaper articles on the subject: death from drinking is the fault of the blockhead drunkards, and even providing them with medical assistance is too generous a gesture. This attitude is subsequently supported by the media by not asking for commentaries from the victims themselves. At the end of the public discussion some articles even stated that they should not be so harsh, because there were also some decent and innocent people who suffered, once again supporting the idea 
that the majority were "blockheads" who suffered because of their vice.

The standpoint of the authors of both samples is that of critical commentator. They stand above the actual event, the responsible and criminal parties, and the commentaries in the media, commenting on the stupidity of all parties involved. That the author of the joke makes the distributor of wood alcohol say that the "buyers were just wood-heads", indicates his criticism of them: only people as irresponsible as those who bought and drank it could believe that "wood-headedness" would remove the fatal effects of wood-alcohol. The same is seen in the demolition joke: the author comments critically on both the attackers (who publish a (regular?) ad to sell their services) and those attacked (who are not clever enough to prevent the tragedy after obtaining appropriate information from the regular reading of newspapers and ads).

\section{SAMPLES 3 AND 4: BLENDED TOPICAL JOKES}

Samples 3 and 4 (belonging to the second category of topical jokes) represent jokes that are usually not created immediately after the events concerned, and mix international issues with local events.

\section{Sample 3}

Sat., Sept. 22, 2001; 15:26

Sent by: Sii-enn-enn (CNN)

Clear Conscience. CNN reports that the Islamic extremists and the Taliban have firmly asserted that they bear no responsibility in the matter of the Estonian presidential election tragedy.

\section{Sample 4}

Sun., Oct. 8, 2001; 19:02

Sent by: Anonymous

To enter the competition, simply look under your one litre methanol bottle cap. If you find the combination of letters "N.Y.", you have won a trip to the World Trade Organization in New York. Transportation is organized by United Airlines with Osama Bin Laden's best soldiers as pilots.

P.S. Tickets will be delivered in a white envelope free of charge. 


\section{Vocabulary, grammar, structure}

The classification in Sample 3 is constructed not on the contrasting of different items but instead on the linking of similar ones. It implies that the Islamic extremists and the Taliban, who assumed responsibility for the terrorist attacks in the USA, are as vicious as those responsible for the outcome of the presidential elections in Estonia. These similar items, the tragic September 11 and September 21, although different in weight, are now both labelled catastrophes. This identifies the audience of the joke as those who consider the results of the presidential elections to be a catastrophe of international proportions. The common features of the two "tragedies" might be their unexpectedness and undesired results. Sample 4 combines the catastrophes under one commercial text that resembles the type of ad used by beverage producers. It also indicates a desire to group similar items: methanol deaths are thus linked to terrorist attacks and anthrax. There is no conflicting classification (i.e. an explicit opposition of two or more parties involved in the discussion). The classification of similar items is a cognitive tool used to manage the manifold social reality.

The key to Sample 3 is that electing Arnold Rüütel to a four-year presidency is a tragedy for the Estonian people and state. In Sample 4, all of the keywords are presented one after another (methanol bottle, New York, World Trade Center, United Airlines, Osama Bin Laden and his "soldiers", a white envelope as a metaphor for envelopes containing anthrax powder), assuming the reader possesses good media competence and background knowledge.

In Sample 3, nominalization marks the author's passivity, with what he hints that he could not say his word in electing the president. Though the election procedure in Estonia takes place through parliament members who are in turn elected by the people, the result of the election does not seem to fulfil everybody's expectations. Indirect speech is used in Sample 3, with CNN cited as a reliable source of information, though here this is used as a stylistic feature to stress the reality vs. joke contradiction.

Sample 4 is very personal in style, like advertisements directed to young people: "simply look under your [---] bottle cap" (implying in a positive mode that you already have one). The ad's addressee is an 
active agent who makes his own decisions ("enters", "looks", "finds" etc.). But this is contradicted by the manipulative advertising text that sells him a low-value generic product that causes death.

The incongruence noted in the analysis of Samples 1 and 2 is also found in Samples 3 and 4. This incongruence lies in the fact that in Sample 3 it is suggested that the reason for the results of the Estonian presidential elections is connected to Islamic terrorist organizations. Sample 4 creates the same effect by mixing the cheerful form of advertising with a serious and dramatic issue, i.e. terrorism and the lack of security.

In both samples, the format imitates media discourse: in Sample 3 that of news, and in Sample 4 that of advertising.

\section{Interpretation}

Without knowing the context for Sample 3, one might assume that something tragic had happened either to the presidential candidates or the newly elected president. If one is familiar with the opinions expressed in the press and broad-based weekly candidate ratings, the thought of linking the two quite different "catastrophes" under one common denominator is not unexpected or misleading. We can see from headlines in the daily newspaper Postimees that this kind of attitude is common (see also discussion below): "Arnold Rüütel the eternal "second"' Sept. 07, 2001 (referring to his supporters from "second", i.e. less well-off Estonia), "Carl Bildt considers the election of Rüütel to the presidency to be normal" Sept. 22, 2001 (while constantly referring to all the drawbacks mentioned with respect to Rüütel), "Arnold Rüütel - a punishment for arrogance" Sept. 22, 2001, "Shock is the best teacher in politics" Sept. 26, 2001, etc.

The institutional background of Sample 3 is relatively obvious: a large proportion of Estonian citizens (and especially the readers of and contributors to www.delfi.ee/jokes) preferred some other candidate for the presidency. Those who supported the candidate of the winning party were older people with relatively low income and also farmers. But the Internet is more representative of the voice of young or middle-aged citizens with at least an average income, as does the daily newspaper referred to above. Thus the joke ech- 
oes the opinion of the institutionalised media and those with relatively more power in Estonian society. For them the election of an old (but good-looking) candidate who has a poor knowledge of foreign languages and a Communist background is a tragedy. The media itself dictates the "tragedy" attitude woven into the topical joke in Sample 3.

Sample 4 also makes extensive use of several media events in one text. The sources are the endless beverage and other advertisement campaigns. The Coca-Cola campaign in July 2001 is one example (e.g. television and newspaper advertisements, as is the article "Coca-cola bottle caps keep disappearing from shops", Postimees, July 13, 2001).

In Sample 4 the institution represented in the joke is that of advertising. Its interests are to make something attractive so as to sell goods. We can name some attempts to make the offer in Sample 4 desirable: "you have won a trip", "best". This contrasts with the actual value of the offer, and thus makes a joke of both the fuss over the tragedies as well as of the advertising genre that tries to sell anything and everything regardless of its real value.

In both samples, we can see that the joking mode enables one to interpret the jokes as a critique of both the president and those who lament the election (it is absurd to consider the results of national elections an international catastrophe); of the several actual catastrophes and the advertising means they were turned into (to discuss the irresponsible blockheads who are themselves to be blamed for their deaths, to curse the police who were too incompetent to find the distributors, to give an account of the mass hysteria about envelopes with white power - also cleverly reflects how everybody grabs the opportunity to take his share of the fuss around a currently hot topic).

Samples 3 and 4 are good examples of what cognitive scientists call the blend - it operates on two input spaces to create a new space with partly inherent and partly emergent structure (see for example Fauconnier 1997). That is a cognitive tool that, when used in jokes, assumes good media competence and background knowledge. 


\section{CONCLUSIONS}

The general trends evident in participating in Internet joking copy that of general use of the Internet. Differences arise during times of more intense media coverage of (possibly dramatic) events. This suggests that people also have a heightened need to comment on the issues, for the amount of information as well as the amount of noise is greater. There are conflicting opinions about the relationship between social conditions and the creation of jokes. Laughter can be viewed as an antidote to legal public discourse (Douglas 1975, Schehr \& Milovanovic 1999). Mulkay (1988), on the other hand, has argued that jokes reinforce existing social structures. Public discourse in the media gives us most of the information about our social reality. Topical jokes are a comment on that genre. Every news item consists of (potential) conflict and (hopefully) a resolution (Moss 1999) to reinforce order in society. Topical jokes seem to play with the established order (and also the temporary chaos) to protest against the artificially prolonged life of the potential media events and how topics are over-exploited by the media, be they important or irrelevant issues (see Ellis 2001).

We should distinguish between content and the manner of linguistic realization (form) to explain the nature of topical jokes. On the one hand, the authoritative form of news dictates a firm belief in what is said, while on the other hand this is contradicted by the all-criticizing anti-authoritarian joke content. Topical jokes are a good way of making a point - both by commenting on the issue, and on a more general plane, on the discourse between media and news itself.

The indicator of a joke in news parody is usually one keyword that deviates from the formal style of regular news. The framework of formal media items is used: news and advertisements. News parodies make use of the conventions of news discourse on the one hand and ridicule on the other (this comes close to the theory of parodic allusion, see Ott and Walter 2000). Parodic allusion describes a stylistic device in which one text incorporates a caricature of another, most often popular, cultural text. The parodic text imitates or exaggerates prominent or representative features of the "original" text and incorporates those features as part of its own textuality. 
Sometimes remarks about a topical event are expressed in the form of event-triggered jokes that are already known to the public (a known joke is presented in original or slightly transformed appearance). The rediscovery of such topical jokes (i.e. plane jokes after September 11) is explained by an event acting as a trigger. But as these jokes do not offer anything new in terms of social reality, they are not cognitively functional and are thus not as frequent, at least in the Estonian sample (e.g. the methanol catastrophe did not result in an increased number of alcohol jokes).

Topical jokes seem to disregard the ready-made formulas for jokes (i.e. only a few news items result in traditional joke cycles (for examples of joke cycles, see Dundes 1987, Kissling 1995, Rahkonen 2000), but new topical jokes arise from news items every day).

The content of topical jokes creates an incongruence between the form reinforcing established order and media power, pointing either to the absurdities in the event itself or the media, which pushes the discussion to the limits of absurdity.

What is the cognitive function of this? News is becoming more and more complicated. Cohen (1998) argues that the way reporters, editors, and newscasters present the news makes it extremely difficult, if not often impossible, for the average citizen to follow, cope with, make sense of, internalize, and use much of the information contained in the news. The stylistic form borrowed from the news genre gives the commentator omnipotence and power to be placed above the catastrophe or otherwise distressful event. The superiority found in humour is here most visible, though the superiority does not imply a definite target (i.e. does not define "us" or "them", "good" or "bad"), but rather shifts the locus of control to the person who tells a topical joke.

Through their conservative form, topical jokes rationalize and objectify an event, purging it of emotions, as is appropriate to the news genre. This might be interpreted as a way of coping with emotional issues, or as a means of protesting against the emotionless nature of media discourse. Topical jokes are critical of the villains and the victims, and more so, even towards the opinion of and means used by the media. They hold a critical position vis-à-vis the parties involved and the genres depicting them. 
In conclusion, we can say that there is a certain functionality to jokes as a mental tool for categorizing and discussing social phenomena. The idea of topical jokes and news parodies is to point to the need to take the constant flow of news, i.e. social reality itself, with a grain of salt.

\section{Comment}

1 'wood alcohol' = methanol, shellac, paint remover. After MEDLINEplus Medical Encyclopedia, http://www.nlm.nih.gov/medlineplus/ency/article/ 002827.htm.

\section{References}

Aikat, D. D. 1998. News on the Web: usage trends of an on-line newspaper. Convergence: The Journal of Research into New Media Technologies. Vol. 4, No. 4, pp. 94-111.

Cohen, A. 1998. Between content and cognition: on the impossibility of television news. Communications: The European Journal of Communication Research. No 23, Vol. 4, pp. 447-461.

Dundes, A. 1987. Cracking Jokes: Studies of Sick Humor Cycles and Stereotypes. Berkley: Ten Speed Press.

Ellis, B. 2001. A Model for Collecting and Interpreting World Trade Center Disaster Jokes. New Directions in Folklore. Vol. 5, pp. 1-12 .

Douglas, M. 1975. Implicit Meanings. Routledge \& Kegan Paul: London. Fairclough, N. 1993. Critical Discourse Analysis and the Marketization of Public Discourse: The Universities. Discourse and Society. Vol. 4, No. 2, pp. 133-168.

Fairclough, N. 1995. Critical discourse analysis: The critical study of language. New York: Longman.

Fauconnier, G. 1997. Mappings in Thought and Language. New York: Cambridge University Press.

Hirsch, K. \& Barrick, M. E. 1980. The Helen Keller Joke Cycle . Journal of American Folklore. Vol. 93, pp. 441-448.

Joon, L. 2000. Etniline huumor sotsiaalses kontekstis: Eesti ja Soome. Manuscript. Tartu University, Department of Psychology.

Joon, L. 2002. Anekdoodid ideoloogia tööriistana: "Hallaste ja Murutari juhtumi" analü̈̈s. Manuscript. Tartu University, Department of Estonian and Comparative Folklore.

Moss, P. D. 1999. Conflict and containment in television news: a case study. Mander, M. S. (ed.). Framing friction: media and social conflict. Champaign: University of Illinois Press, pp. 161-188. 
Mulkay, M. 1988. On Humour: Its Nature and Its Place in Modern Society. Oxford: Polity Press.

Ott, B. \& Walter, C. 2000. Intertextuality: Interpretive practice and textual strategy. Critical Studies in Mass Communication. Vol. 17, pp. 118.

Rahkonen, C. 2000. No laughing matter: the viola joke cycle as musicians' folklore. Western Folklore. Vol. 59, No. 1, pp. 49-63.

Raskin, V. 1985. Semantic Mechanisms of Humor. Dordrech: D. Reidel Publishing Company.

Schehr, R. C. \& Milovanovic, D. 1999. Conflict mediation and the postmodern: Chaos, catastrophe, and psychoanalytic semiotics. Social Justice. Vol. 16, pp. 321-328.

\section{Articles in Estonian Newspapers}

Ametnik näeb Clintonit kolm korda odavamalt. Postimees. May 21, 2002.

September - leinakuu. Veidemann, R. Postimees. Sept. 14, 2001.

Salaviinaäri käib ikka täie rauaga. Jürgen, M. Eesti Ekspress. Dec. 20, 2001.

Metanoolimürgitus tappis Pärnus kaheksa inimest. Postimees. Sept. 10, 2001.

Salaviinaga hauda: süüdi või süütu? Postimees. Sept. 21, 2001.

Metanooliohvri peiedel oli laual salaviin. Postimees. Sept. 18, 2001.

Terroriakt USA-s sunnib kogu maailmas suurendama julgeoleku meetmeid. Postimees. Sept. 11, 2001.

Arnold Rüütel: igavene “teine”. Postimees. Sept. 07, 2001.

Carl Bildt peab Rüütli valimist normaalseks. Postimees. Sept. 22, 2001.

Arnold Rüütel - karistus ülbuse eest. Postimees. Sept. 22, 2001.

Shokk on poliitikas parim õpetaja. Postimees. Sept. 26, 2001.

Coca-Cola pudelitelt kaovad korgid. Postimees. July 13, 2001. 